Published in "Journal of Linguistic Anthropology" 24(1), 2014, 63-83

which should be cited to refer to this work

- Olaf Zenker

Institute of Social Anthropology

University of Bern

zenker@anthro.unibe.ch

\title{
Linguistic Relativity and Dialectical Idiomatization: Language Ideologies and Second Language Acquisition in the Irish Language Revival of Northern Ireland
}

A considerable number of Irish Catholics in West Belfast, originally native English speakers, have started learning the Irish language throughout the Northern Irish conflict in order to feel more Irish. Many of these have developed a strong conviction that the Irish language contains a different worldview from the one embodied in English. However, rather than constituting a plausible representation of relevant differences embodied in the languages themselves, this article puts forward the hypothesis that such a neo-Whorfian endorsement of linguistic relativity might rather be the product of dialectical idiomatization, following from the interplay of prevailing language ideologies and effects of second language acquisition. [Irish language revival, language ideology, second language acquisition, indexical idiomatization, iconical idiomatization, linguistic relativity, ethnicity]

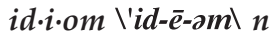

$1 \mathrm{a}$ : the language peculiar to a people or to a district, community, or class : DIALECT

$b$ : the syntactical, grammatical, or structural form peculiar to a language

2: an expression in the usage of a language that is peculiar to itself [...] in having a meaning that cannot be derived from the conjoined meanings of its elements [...]

3: a style or form of artistic expression that is characteristic of an individual, a period or movement, or a medium or instrument

Merriam Webster (1972:413)

\section{Introducing Irish Language Revivalism and Linguistic Relativity in Northern Ireland}

Throughout the second half of the $20^{\text {th }}$ century, the Irish language experienced a remarkable, though locally uneven, revival in Northern Ireland, which has been closely related to the Northern Irish conflict, the so-called "Troubles." Despite its continued minority status in a predominantly English-speaking world, Irish has regained a noticeable presence especially in Irish Catholic Nationalist areas of segregated cities such as Belfast and Derry, even though the revival has not been an exclusively urban phenomenon and has also involved Protestant language enthusi- 
asts (Crowley 2005; De Brún 2006a; Kachuk 1993; Mac Póilin 1997; Maguire 1991; McCoy 1997b; O’Reilly 1999; Zenker 2013).

As in other language revivals in which the minority language is seen as the heritage and emblem of one's own community in need of protection and expansion-as for instance in the case of Corsican (Jaffe 1999), Basque (Urla 1988), Breton (McDonald 1989), Scottish Gaelic (Macdonald 1997), or Ulster-Scots ${ }^{1}$ (Crowley 2006)-local Irish speakers insist that Irish people should be able to speak their "own native language." In fact, many local speakers, virtually all of whom learned English as their first language, explicitly mention this conviction as one of the prominent reasons that made them start learning and practicing the language in the first place. It is thus important to bear in mind that the notion of "native speakers" may refer to both the sequence of language acquisition (i.e., to first language learners) and to ownership and identification with a particular language (i.e., to people regarding a language as belonging to their own community). In many places, these two aspects overlap. However, in the context of heritage revivals and new learners, as in the case of the Irish language in Northern Ireland, they often do not. In such situations, the heritage language is frequently regarded as one's own native language, while not being the linguistic variety of first acquisition. ${ }^{2}$

Such cases of linguistic nationalism frequently not only use language as an ethnic marker of group identity, characterizing it as internally shared while making members different from outsiders. Instead, such language ideologies (Jaffe 1999; Kroskrity 2000, 2004; Schieffelin et al. 1998; Silverstein 1979; Woolard and Schieffelin 1994) often further incorporate romantic notions of a profound relationship between a particular language and the ways, in which it influences the outlook and worldview of its speakers (Schlee 2008:102). Such representations of the Irish language are also quite prominent among local Irish learners and speakers-called "Gaeilgeoirí" in Irish-and I will specifically focus on this aspect dealing with the interrelations between "language, thought, and reality" (Whorf 1956) that, for a long time, has been discussed in terms of "linguistic relativity."

Within the academic literature and within anthropology in particular, the idea of "linguistic relativity" is most strongly associated with the writings of Benjamin Lee Whorf (1956), often incorporating Edward Sapir as another of its proponents, thus leading to the familiar descriptor of the "Sapir-Whorf hypothesis." However, earlier European writers advancing similar ideas prominently included Humboldt (1988[1836]) and, before him, Herder (2002[1765-1793]:33-166). While the precise nature of what Whorf asserted regarding the interdependencies between language and thought has been hotly debated (Schlesinger 1991), it has become somewhat of a commonplace to distinguish between a strong version of linguistic relativity: an uncircumventable, inescapable linguistic determinism, and a weak version of linguistic relativity which assumes some influence to be exercised by a particular language on the ways in which its speakers apprehend their world, even though these influences can be bypassed or at least diminished through critical reflection (Rosch 1977; Werlen 2002:2, 28).

With regard to the strong version of linguistic determinism, a number of arguments have been advanced as to why such a position is not tenable. These counterarguments usually focus on questions of translatability, multilingualism and the impossibility of radical alterity (Davidson 1989:159-160; Schweizer 1998:55-56; Werlen 2002:27-28). At the other end of the continuum characterizing linguistic relativity, we find arguments that, within an anthropological context at least, sound as true as trivial. Of course, different languages, and "cultures" more generally, predispose people to perceive, think and act in certain ways, otherwise, anthropology as an academic endeavor would be somewhat pointless. However, instead of either quickly dismissing the strong program or emphatically embracing the weak program of linguistic relativity, the position taken here is that the interesting questions on linguistic relativity actually reside in between these extreme versions, as Schlesinger (1991:31) observes: in what ways and to what an extent do linguistic characteristics 
really exercise an influence on perception and behavior in an empirically observable way?

Such an approach of empirically investigating the extent of linguistic relativity through correlating linguistic variables with nonlinguistic patterns of thought and behavior has come to direct much research in recent decades (Werlen 2002:26-27). Within this field of empirical study, three approaches have been distinguished (Lucy 1997:295-304): first, starting from differences between languages in terms of their structure of meaning, structure-centered approaches have studied the relation, for instance, between grammatical number marking and cognition among speakers of American English and Yucatec Maya (Lucy 1992); second, domain-centered approaches have investigated, how a certain domain of experienced reality is encoded and construed in various languages, like in the classic studies of color categories (Berlin and Kay 1969; Brown and Lenneberg 1954, 1958; Lucy and Shweder 1979); third, behavior-centered approaches have attempted to explain behavioral discrepancies in terms of underlying linguistic differences, as in Bloom's (1981) study of the interrelation between counterfactual markers and speakers' facility with hypothetical reasoning in Chinese and English.

Without going into the details of such studies (at least some of which seem to demonstrate weak forms of linguistic relativity), it is important for the context of this text to emphasize that they all strive hard methodologically to escape circular reasoning through empirically correlating linguistic with nonlinguistic, usually experimental, data (see Lucy 1997). In other words, unless an independent variable of linguistic difference can be shown to systematically influence the dependent nonlinguistic variable, claims to linguistic relativity remain empirically unwarranted.

Because, with regard to native Irish speakers, neither my informants nor I actually have any such nonlinguistic data on language-induced patterns of thought and behavior (see the next section on data), within the scope of this article it will be impossible to reach sufficiently warranted conclusions regarding the actual impact of differences between English and Irish. However, this will not prevent me from developing an alternative hypothesis as to why so many of my friends and informants maintained quite far-reaching claims to linguistic relativity. Put differently, while many local actors strongly identified with notions of linguistic relativity because they were convinced that, given the linguistic evidence they had (see below), such ideas were simply true, I will offer an alternative explanation for the existence of such convictions, which-while empirically testable in principle-for the time being has to remain a mere hypothesis, given the lack of additional data.

Within arguments about linguistic relativity, languages usually end up being imagined, and subsequently compared, in some bounded, homogeneous and ideal-typical form-for instance in Whorf's famous "Standard Average European" in contradistinction to Hopi (Whorf 1956). Such "pure" linguistic forms are then taken to exercise systematically different influences upon their respective speakers, who tend to be conceived in equally idealized ways as "native speakers." In this way, arguments about linguistic relativity implicitly or explicitly make reference to ideal-typical "native speakers," and how they are shaped by the structures of their respective languages, whether or not these speakers notice themselves. Ideas about "the native speaker" as an ideal language user with complete competence in a language perceived as being bounded and fixed to a homogeneous speech community and typically linked to a nation-state have been recently challenged. Focusing on wider sociocultural and political contexts, studies have questioned the empirical accuracy of these ideas under conditions of global migration and multilingualism, highlighted the political nature of (not) claiming "native speakership" and problematized the implications of "native speaker" discourses for regimes of standardization (Doerr 2009).

Such arguments have introduced important insights into the multilinear and diverse pathways of acquiring and speaking "a" language, which support, subvert and complicate each other in ways that belie simplistic ideas about bounded and homogeneous speech communities. At the same time it seems clear that arguments 
about linguistic relativity cannot do without at least some typified assumptions about "native speakers" in the sense of first language learners (see above). Only by evoking the relative presence (or absence) of differences in the thought and behavior of such native speakers, allegedly induced by characteristics of their respective languages, and by comparing such models with empirical data, does it become possible to get a grip on questions of linguistic relativity. My informants in Northern Ireland constantly evoked such assumptions about the ways in which native Irish speakers and native English speakers saw the world differently. Consequently, when developing an alternative hypothesis about the reasons behind local convictions about linguistic relativity, I will equally put forward idealized assumptions about native speakers of both Irish and English and will use them as ideal-typical reference points. For the logical structure of this argument, it is thereby immaterial whether or not monolingual native Irish speakers still exist. As a matter of fact, as my own argument builds on a dialectic between prevailing language ideologies and effects of the sequence of acquiring possibly several languages, monolingualism is no prerequisite for any future empirical test of my hypothetical argument.

In order to explain the often quite strong beliefs in linguistic relativity among Northern Irish Gaeilgeoirí, I will thus put forward a hypothesis that focuses on the dialectics between prevailing language ideologies on the one hand and effects of adult second language acquisition on the other. I will start with outlining the research contexts and the kinds of data that I obtained; I will thereby highlight the hypothetical nature of my overall argument, attempting to offer an alternative explanation for the existence of language ideological positions on linguistic relativity that I came across in Northern Ireland. On the one hand, this argument will make use of a language ideology approach, laying out the ideological landscapes that have been partly shaping the ways in which language practices have been locally conceived; on the other hand, I will go beyond what is often conceived as the main task of language ideological analyses through offering linguistic reasons other than those evoked by my informants to better account for their strong commitments to linguistic relativity.

Against this backdrop, I will give a brief historical overview on the recent Irish language revival in Northern Ireland. In a third step, I will describe some of the linguistic evidence that my informants offered to me in order to substantiate their claims that Irish people speaking their "own native language" actually inhabited a world very different from the one inscribed in English. In a fourth step, I will explore the multifaceted web of locally prevailing language ideologies, which shapes Irish and English language usages in West Belfast and simultaneously gets reproduced and transformed through such linguistic practice in complex ways. Reconstructing the embeddedness of Irish language use in power asymmetries, ethno-nationalist politics and violent conflict, I show that a dominant ideological strand has iconized Irish as the "own native language" of the Irish nation and, metonymically, as emblematic of its distinctive, also language-mediated worldview. I refer to this process of both conceptualizing and acquiring a "foreign" (i.e., hitherto not practiced) idiom as "one's own native language" in terms of "iconical idiomatization." This idiomatization, especially its conception of looking differently onto the world when speaking Irish rather than merely acquiring another ethnic marker in contradistinction to oppressive Britishness, has resonated well with the ethnicized landscape of the Northern Irish conflict that has emphasized profound differences between friends and foes rather than their commonalities.

In a fifth step, I will inverse the direction in my focus on the interplay between language ideologies and language usages, exploring the impact of the latter on the former. Taking my cue from linguistic research on language acquisition regarding idioms, I will argue that the ideological appearance of linguistic relativity, which leads to a relative "othering" of the Irish language vis-à-vis the English language, is also an indexical effect of adult second language acquisition, in the course of which learners disassemble complex Irish expressions into their translated component meanings in ways that native learners-according to my hypothesis-simply do not, 
which causes the appearance of surplus meanings and idiomaticity, where there are probably none for native speakers. I use the expression "indexical idiomatization" to characterize this process, in which the mistaken idiomaticity of Irish expressions, as produced (rather than revealed) in concrete acquisition contexts of adult second language learners, becomes indexical of linguistic relativity at the ideological level.

I conclude arguing that the dialectics between iconical idiomatization, framing communicative practices in terms of neo-Herderian language ideologies, and indexical idiomatization, producing neo-Whorfian ideologies on the basis of second language acquisition experiences, constitute a more plausible hypothesis for explaining the widespread disposition among Northern Irish Gaeilgeoirí to conceive the relationship of language and thought in terms of "linguistic relativity" than their own assertions of actual linguistic relativity.

\section{Data and the Hypothetical Nature of the Overall Argument}

The data used in this article was produced in one of the heartlands of the language revival in Northern Ireland, namely the strongly Irish Republican enclave of Catholic West Belfast, where I did 14 months of fieldwork in 2003 and 2004 on the relationship between the Irish language and Irish identity (Zenker 2006, 2009, 2010a, 2010b, 2011, 2012, 2013).

During fieldwork, I did participant observation in numerous Irish language contexts, including formal Irish language classes (5 weeks of full-time classes as well as 4 weekly classes for a whole academic year), the Irish language, culture and arts center Cultúrlann McAdam Ó Fiaich, the bar of the all-Irish club Cumann Chluain Árd, and in numerous informal activities with local Gaeilgeoirí that I got to know during fieldwork.

Besides participant observation, my research also focussed on a series of 145 in-depth interviews with a total of 28 key informants. These interviews were conducted-among others-in order to reconstruct an oral history of the local language scene as well as locally prevailing language ideologies. In search of a somewhat representative sample, I selected interviewees with an eye toward age, gender, class, and degree of involvement with the Irish language. In the course of both data collection and subsequent analysis, the data was source-critically evaluated regarding its validity, first, concerning the mutual implication of interactional context (including my role as researcher) and informational content; and second, in terms of a triangulation that tested the reliability of my informants' accounts by scrutinising their internal consistency and by comparing them with data obtained from other informants, archival material as well as the existing literature. ${ }^{3}$

Given that the overall focus of my project was on the interplay between representations and practices in the interrelation of the Irish language and Irishness among Gaeilgeoirí in Catholic West Belfast (Zenker 2013), I paid great attention to the numerous ways in which locals spoke about, and practiced, the Irish language-and parts of the results regarding dominant language ideologies are summarized below. ${ }^{4}$ In this process, claims to linguistic relativity were frequent, and noted as ideological statements quite typical for language nationalist revivals in general. However, at the time, I did not research any further the actual evidence offered by my friends and informants to substantiate their linguistic relativist claims. It was only after fieldwork in the course of data analysis that I recalled the often repeated linguistic examplesmostly (but not exclusively) on emotions, possessions and place names (see below) offered informally by my informants during pub visits, in conversations over tea at home, while spending time together on hill walks, during breaks at language classes, and the like.

Especially the context of Irish language classes turned out to produce many of those "literal" translations (a concept to be problematized below) that were subsequently offered as evidence in support of linguistic relativity. Garland (2010) provides detailed descriptions of interactions in Irish language classrooms of a language 
college in Donegal (Republic of Ireland), highlighting how, in the attempt to get a grip on Irish linguistic constructions through the medium of English, learners and teachers often engage in what they regard as "literal" translations. Garland's analysis shows how learners use their general knowledge about such constructions in Irish in order to produce "mock translations," which communicate their linguistic expertise, even when lacking knowledge of a specific linguistic structure or vocabulary item (Garland 2010). Although I did not come across such forms of mock translations myself, I vividly recall similar dynamics in the attempt to "literally" translate Irish constructions into English. In my experience, however, this was often a process initiated by learners rather than by teachers, who more often tried (mostly in vain) to get us to learn complex expressions holistically. Interestingly, it has been one of the doctrines of the above-mentioned all-Irish club Cumann Chluain Árd to teach Irish exclusively through the medium of Irish, precisely in order to prevent such "literal" comparisons (Zenker 2013:57).

Thus without systematically recording examples of "literal" translations regarding emotions, possessions, and place names to be presented below, I still did come across them many times both in classroom situations and in informal conversations. In fact, when recently discussing these examples with Irish-speaking friends in Belfast, they immediately confirmed my observation and offered further examples they had encountered in similar situations. As I have mentioned, then, both the reported arguments of my informants in favor of linguistic relativity and my own argument, putting forward an alternative explanation for such widespread neo-Whorfian beliefs, remain hypothetical in nature and in fact, could be described as competing language ideologies about the impact of Irish linguistic structures on the thought and behavior of their native speakers. In part, my argument will indeed make use of a language ideology approach, showing how the prevailing ideological landscapes have predisposed local Gaeilgeoirí to conceive the language in certain ways; this I will refer to as "iconical idiomatization." However, my argument also goes beyond an ideological approach to claim that it is the effects of adult second language acquisition, which cause the appearance of surplus meanings and hence linguistic relativity-a process I will call "indexical idiomatization." I will argue that this constitutes in fact a better hypothesis for explaining local commitments to linguistic relativity than the hypothetical existence of actual linguistic relativity.

\section{The Irish Language Revival in Northern Ireland: A Brief Historical Overview}

Despite fundamental changes in recent years, society in the North of Ireland still remains divided along nearly co-extensive lines of religious, ethnic, and political self-ascriptions, ensuring that-as public opinion data persistently shows (Coakley 2007; Trew 1998) — most Catholics see themselves as Irish and politically subscribe to the Nationalist/Republican agenda of uniting Ireland, whereas most Protestants identify themselves as British and, as Unionists/Loyalists, wish to maintain "the United Kingdom of Great Britain and Northern Ireland" (Coulter 1999:10-22). In cities like Belfast, this social divide is manifested in considerable residential segregation (Doherty and Poole 2000:189). This also strongly applies to West Belfast, consisting of two areas-a Protestant one to the north and a larger Catholic area to the south-that are largely physically divided by so-called "peace lines" across which interaction continues to be limited. It is hence not surprising that almost all of my informants in Catholic West Belfast came only from the Irish Catholic Nationalist/ Republican community.

As mentioned before, the Irish language has recently experienced a remarkable revival in and beyond Catholic West Belfast. Irish belongs to a group of six Celtic languages. Though as a Celtic language Irish is part of the Indo-European family of languages, it is only distantly related to the Germanic branch of which English is a part (Hindley 1990:3; Ó Murchú 2000:3; Price 2000; Schrijver 2000). Historically, over the course of Ireland's long colonial history and especially in the $19^{\text {th }}$ century, the 
prevailing language, Irish, was increasingly replaced by English. Despite the continued existence of the "Gaeltacht" — that is, small areas inhabited by native Irish speakers along the west coast-Irish as a first or community language has thus continued to decline, despite the attempts of several cultural revival movements since the late $19^{\text {th }}$ century leading to rising numbers of people who claim to be able to speak it to some extent (Hindley 1990; Hutchinson 1987; Nic Craith 1999; Ó Murchú 2000; Purdon 1999; Zenker 2013).

After Partition in 1921, the fate of Irish took quite different directions north and south of the border (Antonini et al. 2002): in the new independent state in the South, Irish was recognized as the first official language and made a compulsory subject in all schools, and all aspects of administration were handled bilingually (Maguire 1991:41; Purdon 1999:50). By contrast, in the new "Northern Ireland," state policies reflected the attitude that Irish was a foreign language (Mac Póilin 2006:129), although firmly established educational segregation allowed it to be taught as an optional subject in Catholic grammar schools in and beyond Belfast (Zenker 2012:26). It is thus not surprising that toward the mid- $20^{\text {th }}$ century the Irish language had a rather limited presence in Catholic West Belfast. Yet as historical sources, my own fieldwork material, as well as the historiographical ${ }^{5}$ and ethnographical ${ }^{6}$ literature show, this situation changed considerably from the 1950s onward, when a local language revival began to gain momentum. While grossly simplifying the underlying dynamics, it can be said that this success has been mainly due to two factors: first, the establishment of a quite effective language "supply" by a small circle of committed language activists; and second, increasing local "demand" for practicing the language, a demand that in complex ways has been stimulated by the "Troubles" (Zenker 2012).

During the 1960s, a group of language enthusiasts founded "Ireland's first urban Gaeltacht" (De Brún 2006b:12) in Catholic West Belfast, where Irish has been spoken as the everyday language ever since. This establishment of a small Gaeltacht neighborhood proved particularly consequential because it gave the language a permanent location from which further initiatives could develop (Maguire 1991; Nig Uidhir 2006). As families in this neighborhood raised their children with Irish as their first language, Irish-medium education became the next pressing issue. These same Irish speakers thus also founded and ran the first Irish-medium school in the North of Ireland despite the disapproval of educational authorities, who for more than a decade refused to support the school financially. Initially the school only catered to children from the immediate community, but soon it was also opened to pupils from surrounding neighborhoods, who had acquired some Irish while attending a language-immersion nursery that had also been established within the urban Gaeltacht. The Irish-medium school and nursery were later to function as "blueprints" for many other educational institutions throughout the entire North of Ireland (Mac Corraidh 2006). Within the wider networks of these activists, additional language initiatives appeared, including the foundation in 1991 of the above-mentioned center Cultúrlann McAdam Ó Fiaich, which has since provided a focal point for local Irish-medium interactions (Zenker 2012:27-34).

Corresponding to this expanding infrastructure of language supply, there has also been a growing demand for Irish language activities due to a pronounced ethnicization of everyday life because of the Troubles. Beginning in the 1970s, thousands of locals started learning Irish in informal evening classes, which began to proliferate in social clubs, schools, pubs, parish halls, and private houses in Catholic West Belfast. Others learned the language during increasingly long terms of imprisonment (Feldman 1991:204-245; Kachuk 1993:152-258; Mac Giolla Chríost 2012; O'Reilly 1999:17-31). From the 1980s onward, many Republicans within the IRA and its political wing, Sinn Féin, who had hitherto not ascribed much importance to the Irish language also began to promote it (McKeown 2001). In addition, increasing numbers of parents sought Irish-medium schools for their children, and such demand spurred the founding of ever more Irish-medium schools. Especially since the 1990s, this has led to an explosion of Irish-medium education. Together, all of 
these factors have led to a dramatic increase in the actual practice of the Irish language within Catholic West Belfast and beyond-developing almost exclusively on the basis of second language acquisition (Zenker 2012:34-41).

\section{The Case for a Distinctive Worldview Induced by the Irish Language}

In the course of my ethnographic fieldwork in West Belfast, I was repeatedly told by various Gaeilgeoirí that learning and speaking Irish had introduced them to a completely new "world." Many people highlighted that, compared to English, Irish was a very poetic language, which expressed things much more gently and subtly. Others emphasized that the Irish language somehow spoke more closely to their emotional life than English, despite the fact that they were native English speakers who had acquired Irish only as adult second language learners. Others, again, claimed that they even became a different person when speaking Irish, and some further proclaimed that speaking Irish with local Protestant Gaeilgeoirí made possible a reduction of their political antagonisms in ways that the same conversation in English could never achieve. Given the strong socialist political outlook of many of my Irishspeaking informants, discussions about the language also included questions of capitalism and private property. Here some argued that the Irish language enshrined a quite different understanding of what it meant "to have" and "to possess," thus showing that a world different from British capitalism and imperialism was possible.

Yet what was the linguistic evidence that was offered in order to substantiate these, at times, quite far-reaching claims of linguistic relativity? Given that the conversations on the language-induced distinctive worldview usually took place in informal conversations or interviews on some other topics (see above), the evidence offered was typically of an anecdotal nature. Against this backdrop, I will focus here only on three exemplary issues that were repeatedly highlighted to me-namely expressions of feelings, phrases of having or possessing something and the meaning of place names - in order to illustrate recurrent forms of emic argumentation.

In the Irish language, emotions and feelings are typically expressed in constructions like the following:

Tá brón orm = I am sad

Tá ocras ort = You are hungy

Tá náire air $=$ He is ashamed

When using these examples in our conversations, my interlocutors pointed out that the literal translation of these expressions always combined the verb "to be" (Tá) with the noun, expressing the emotion (e.g., "brón" = sadness), and a prepositional pronoun, combining the preposition "on" (ar) with the respective personal pronoun (e.g., "orm" = on me), even though my informants obviously did not use this technical linguistic vocabulary. Thus the sentence "Tá brón orm," stating "I am sad," was said to "literally" translate into: "Sadness is on me." In the same vein, "Tá ocras ort" was given the "literal" translation "Hunger is on you," whereas "Tá náire air" was explained as "literally" declaring that "Shame is on him." This showed, it was claimed, that the Irish language did not conceive of feelings as personal properties characterizing the afflicted person as such (as in English), but rather as independent states of affairs that come and go to people, without fully taking possession of them. Thus in Irish, one informant went on to explain, somebody was not a depressive person in any essentialized sense (as in English), but rather somebody who was-for the time being-under the influence of sadness.

A second recurrent example consisted in Irish phrases, expressing that somebody had or owned something:

Tá rud beag Gaeilge agam = I have/I speak a little bit of Irish

Tá teach de mo chuid féin agam = I have a house of my own

Is léi an siopa $\sin =$ She owns that shop 
Again, people pointed out that the literal translation of these expressions combined either the verb "to be" (Tá) or the copula (Is) with a noun, referring to an object of possession (e.g., "Gaeilge" = Irish), and a prepositional pronoun, combining either the preposition "at" (ag) or "with" (le) with the respective personal pronoun (e.g., "agam" = at me or "léi" = with her). The first example was hence "literally" translated as "A little bit of Irish is at me" rather than the locally more conventional "I have/I speak a little bit of Irish" (I will address the implications of the ambiguity between "having" and "speaking" a language in the conclusion). Equally, the Irish phrase "Tá teach de mo chuid féin agam" was given the "literal" translation "A house of my own (share) is at me." Finally, the last example "Is léi an siopa sin," stating "she owns that shop," was revealed as having the "literal" meaning "That shop is with her." All these turns of phrases on possession showed, it was argued, that the Irish language enshrined a somewhat anti-materialist, if not anti-capitalist, and more transcendental or spiritual attitude toward material objects, which only came and stayed "at" or "with" people for some time, but could not be truly "owned" by them. Thus, I was told, a too this-worldly orientation toward possessions was discouraged by the linguistic outlook in Irish. By contrast, the English language projected people to own or have things and hence stressed a much more permanent relationship that could be established, and was actively achieved, through human agency. This latter "English" attitude, I was told, thus fostered arbitrary beliefs in the seemingly inevitable nature of capitalism and even imperialism, to which Irish speakers did not fall prey that easily.

A third and last domain of linguistic evidence used by local Gaeilgeoirí to support their thesis of a more "meaningful" attitude in Irish toward the world consisted in local place names. The great majority of place names in Ireland have their origin in the Irish language, yet Anglo-Norman colonization since the $12^{\text {th }}$ century started a process of anglicizing such names that, arguably, has continued until today (Mac Giolla Easpaig 2008:165-166). Whereas the anglicized spelling of principal town names in Ireland had been standardized by the early $19^{\text {th }}$ century, this was not the case for townlands and minor feature names in rural areas. This was achieved, however, when the Ordnance Survey with its first large-scale survey of Ireland in 1824 anglicized and standardized spellings of all place names (Mac Giolla Easpaig 2008:166-167).

Given that the Ordnance Survey spelling of place names has served as the official standard spelling ever since (Mac Giolla Easpaig 2008:167), native English speakers in Northern Ireland have usually lived in places referred to by a prototypical "proper name," famously characterized by John Stuart Mill as "a word which answers the purpose of showing what thing it is we are talking about, but not of telling anything about it" (Mill 1973[1843]:33). In other words, apart from referring to the place at issue, these place names usually carry no further meaning for such English speakers. There is no need here to engage with the extensive and controversial debates in the philosophy of language on the semantic question of whether or not a descriptive element beyond mere reference belongs in the meaning of all proper names (see Cumming 2012). Instead, for the current purposes it suffices to highlight that the standardized anglicized spellings of formerly Irish-language place names usually exhibit no obvious descriptive characteristics that would be intelligible to monolingual English speakers. This situation is changed quite profoundly, however, once such people start learning Irish as a second language, because-as I could observe myself again and again when attending several Irish language classes in Belfast-the reconstruction of the former Irish-language versions of anglicized place names typically forms part of the curriculum. Thus I believe that almost everyone in adult language classes in West Belfast at some point is likely to come across the Irish-language origins of local place names such as:

Belfast $=$ Béal Feirste $=$ mouth of (or approach to) the river Farset $/$ the sand-bank ford

Falls Road (arterial road through Catholic West Belfast) = Bóthar na bhFál = hedge road $/$ road of an area enclosed by a hedge 
Shankill (area in Protestant West Belfast) $=$ Seanchill $=$ old church

Derry $=$ Doire $=$ oak grove

Dublin $=$ Dubhlinn $=$ black pool

Against this background, it is revealing that I met several native English speakers who-having learned Irish as a second language - told me that their new capacity to suddenly understand the Irish origins of local place names had reconfigured the whole landscape with an additional layer of meaning. Put differently, their growing language competence had abruptly turned local place names into "speaking names," that is, names drawing additional "meanings from assumptions about the significance of their roots" (Kanavou 2011:2). Thus, had people before lived in a city that just happened to be called "Belfast," some of them felt that this place was now characterized, and permeated, by an additional, hidden meaning through the reference to the mouth of the sand-bank ford. In short: the Irish language was presented as restoring an additional meaning that Anglicization had corrupted and that the English language consequently lacked.

These three exemplary domains illustrate the linguistic evidence that my informants repeatedly suggested in order to substantiate their claim that the Irish language indeed embodied a worldview considerably different from the one predisposed by the English language. Against the backdrop of the methodological argument on the necessity to independently establish and correlate both linguistic and nonlinguistic data, it is clear that this linguistic evidence in itself cannot function as sufficient proof for a truly existing linguistic relativity. In the following, I will develop an equally hypothetical argument, focusing on prevailing language ideologies as well as effects of adult second language acquisition (more specifically the inverse modes of idiomatization they entail), that-so I contend-better explains local commitments to linguistic relativity than the existence of any actual linguistic relativity.

\section{Local Landscapes of Language Ideologies and Iconical Idiomatization}

The divergent beliefs and interpretations that my informants offered regarding their various linguistic examples, proving to them the existence of a specific Irish worldview embodied in "their" language, have to be seen in the wider social and political context of the Northern Irish situation. In other words, these attitudes cannot be merely taken as individual and idiosyncratic attempts at making sense of linguistic and nonlinguistic experiences, although this is of course what they partly are as well. Instead, they have also been part of their respective historical landscapes of power asymmetries between the oppressive British state and Irish Catholics as second-class citizens, ethno-nationalist politics and violent conflict about the constitutional status of the Irish North, in which these attitudes emerged and which, in turn, they helped to reshape. In other words, such attitudes are also ideological, both with regard to language and the world beyond.

Over the past decades, a thriving body of research has developed in linguistic anthropology, investigating speakers' linguistic awareness as well as embeddedness in their social and cultural contexts in terms of "linguistic" or "language ideologies" (Kroskrity 2004:497; see Jaffe 1999; Kroskrity 2000; Schieffelin et al. 1998; Silverstein 1979; Woolard and Schieffelin 1994). In contrast to former conceptions in linguistics, such research on language ideologies has followed Michael Silverstein's early dictum that the evolution of linguistic structure is crucially shaped also by actors' linguistic ideology: "The total linguistic fact, the datum for a science of language, is irreducibly dialectic in nature. It is an unstable mutual interaction of meaningful sign forms contextualized to situations of interested human use mediated by the fact of cultural ideology" (Silverstein 1985:220). Thus studying language ideologies in terms of "the situated, partial, and interested character of conceptions and uses of language" (Errington 2001:110), this heterogeneous field of research-as Kroskrity (2004:498) 
emphasizes-“simultaneously problematizes speakers' consciousness of their language and discourse as well as their positionality (in political economic systems) in shaping beliefs, proclamations, and evaluations of linguistic forms and discursive practices." However, although situated at the intersection of language use and structure, language ideologies are not concerned with language alone (Woolard 1998:3). Instead, they are linked to divergent interests of groups and individuals, are usually multiple and contested, held by actors to varying degrees of awareness, and often made to play a crucial role in the construction of collective identities (like ethnicity or nationality) (Kroskrity 2004).

Against this backdrop, the Irish language scenery in West Belfast can be conceived as a symbolic landscape, prestructured and permeated by such language ideologies that operate within different dimensions and at variable scales. For the purposes of this text, it suffices to concentrate on the macro-level of most general language ideologies related to the Irish language, for which I discerned three main ideological strands among local Irish speakers (Zenker 2013:133-143; see also Kachuk 1993 and O'Reilly 1997, 1999). A small group consisting mainly of language lobbyists articulated a rights activism, depicting the Irish language as an issue of "human," "civil" and/or "minority rights" that was above narrow political concerns such as the constitutional status of the North of Ireland. From this perspective, the language was sometimes viewed as a precious yet endangered object of culture. It is important to note, however, that in this context the term "culture" was used to refer not to a distinctive "ethnic culture" typically associated with Irishness (as in the following two positions) but to an overarching "human culture," the diversity of which had to be protected as an end in itself through a kind of cultural environmentalism (Zenker 2013:135-137). ${ }^{8}$

In contrast, for those propagating the second ideological position of language ethnicisim, Irish represented a fundamental yet largely lost element of their own "Irish culture and identity." However, ethnicists argued for a strict separation between issues related to the Irish language and the politics of unifying Ireland. These actors therefore tended to be suspicious of any public "performances" of the Irish language by Irish Republican politicians, whom they accused of "hijacking" the language, abusing it as a mere means to their ultimately political ends (Zenker 2013:137-140).

Those associated with the third ideology of language nationalism shared with ethnicists the conviction that the Irish language was an important element of Irishness, which had to be reappropriated. Yet nationalists rejected the suggestion that they (or their allies) had "hijacked" the language, arguing that by speaking Irish one already was and should be engaged in the political struggle for decolonizing Ireland and, thus, liberating it from its external British oppressors (Zenker 2013:140-142).

Despite some important differences, the ethnicist and nationalist ideologieswhich, to my knowledge, prevail locally-thus have one important feature in common, namely the representation of the Irish language as a crucial element of their own "Irish culture" in need of repossession. This notion of Irish as "our own native language," which I encountered again and again in conversations with locals, seems to have become not only very widespread, but also highly politically relevant in Catholic West Belfast only since the 1970s, although the close link between Irish and Irishness was propagated in Nationalist discourses all over Ireland as far back as the $19^{\text {th }}$ century (Andrews 2000a, 2000b; Hindley 1990:21-42; Hutchinson 1987; Kachuk 1993:112-151; O’Reilly 1999:32-48; Zenker 2012).

Against the backdrop of these dominant strands within language ideologies, it became evident in the course of my interviews that many if not most local Gaeilgeoirí-virtually all of whom are non-native speakers, and often adult second language learners-had clearly engaged with the language in order to feel more Irish, and for language nationalists at least, to additionally emphasize their own distinct ethnicity vis-à-vis the external British oppressor (Zenker 2013:118-119,143-145). However, many language ethnicists and nationalists did not stop at equating the Irish language with the Irish nation, merely using Irish as an ethnic marker of Irishness. 
Instead, they added further ingredients to this neo-Herderian language ideology, in which language, nation and territory appeared naturally and organically congruent (Woolard 1998:16-18). Their statements framing linguistic evidence, as presented in the previous section, pointed toward further ideological facets, characterizing a specific Irish worldview inscribed into the language: first, a more poetic, gentle and nonessentialist attitude toward emotions and feelings; second, a more antimaterialist, anti-imperialist and transcendental stance on possessions; and third, a more spiritual attention to local landscape, inscribed with additional and hidden meanings. Such neo-Whorfian notions were interwoven with language ethnicism and nationalism in various ways, even though sometimes they could also be found in connection with rights activism.

In their influential study on how language ideologies frame and manage seemingly "neutral" linguistic differentiations, Judith Irvine and Susan Gal (2009) identify three important semiotic processes involved in that work: iconization, in which linguistic features appear to depict a group's inherent nature or essence; fractal recursivity that projects a salient opposition onto lower or higher levels of relationship; and erasure, in which features inconsistent with a particular ideology are rendered invisible (Irvine and Gal 2009:403-404; see also Gal and Irvine 1995). Of these, iconization seems most relevant for my current discussion in that dominant language ideologies in West Belfast have evidently treated the Irish language iconically, that is, "not just as a dependable index of a social group [the Irish nation] but as a transparent depiction of the distinctive qualities of the group" (Woolard 1998:19).

Harking back to the epigraph of this article-the entry in Webster's Seventh New Collegiate Dictionary on "idiom"-it is possible to further specify the content of this iconization in terms of the first and the third of the three principal meanings of "idiom": Irish has become an icon of the Irish nation in the sense of both being its distinctive language with recognizable linguistic peculiarities (i.e., as an ethnic marker) and comprising a style or form of thinking characteristic of the inherent nature or essence of Irish "culture and personality" (i.e., as its distinctive worldview).

The local landscape in West Belfast has thus been profoundly prestructured and permeated by preexisting language ideologies, dominantly framing the Irish language in terms of "the iconical idiom" of the Irish nation, long before any individual Irish learner could actually begin engaging with the language. This has predisposed local Irish Catholics to indeed appropriate this "foreign" (i.e., hitherto not practiced) idiom in such terms that this language appears not only as "one's own native language," but also as a much more comprehensive icon of distinctive "Irish ways and Irish laws," a specific Irish worldview. This process of making a hitherto not practiced idiom profoundly one's own-both in conception and through language acquisition-can thus be described as "iconical idiomatization."

\section{Idioms, Language Acquisition, and Indexical Idiomatization}

So far, I have focused on the ways, in which the wider landscape of multiple language ideologies in West Belfast has dominantly represented, and thereby framed, the practice of the Irish language through iconical idiomatization. Inversing this focus, I now scrutinize the potential impact that Irish language acquisition and usage has had in (re)producing such ideological structures. In order to do so, I will begin with what might seem a detour, drawing inspiration from the second and remaining meaning of "idiom," as specified in the epigraph, namely as "an expression in the usage of a language that is peculiar to itself [...] in having a meaning that cannot be derived from the conjoined meanings of its elements" (Merriam-Webster 1972:413).

Regarding this second meaning, the Oxford Companion to the English Language defines an idiom as a phrase having a figurative meaning that is comprehended in regard to a common usage of that expression, and which is separate from the literal meanings or definitions of the words of which it is made (McArthur 1992:495-496). In other words, idioms constitute set phrases or fixed multiword strings which contra- 
dict the principle of compositionality. This principle of compositionality consists in the normally prevailing principle that the meaning of a complex expression is determined by the meanings of its constituent expressions and the rules used to combine them (Szabó 2008). Because idiomatic phrases are semantically equivocal and hence appear more complex than nonfigurative speech, psycholinguistic research on language acquisition has for a long time assumed-following Piaget's (1928) stage model of cognitive development-that children learn such complex expressions only at a later stage of lexical development, that is, earliest at primary school age (Häcki Buhofer 2007:855-857, 860-862).

However, recent empirical research has shown that younger children have actually much less difficulty in understanding and using idiomatic phrases than hitherto assumed. As language acquisition, in any case, is not a one-off event, but rather a continuous process of revisiting and reworking already developed linguistic knowledge, children from the early age of three years onward have been shown to learn and use such idiomatic expressions. While these children only acquire a retrospective understanding of the polysemic nature of idioms at some later stage, young primary school children were interestingly found to activate the holistic, composite meaning of idioms more frequently than the literal meanings of their constituent words (Häcki Buhofer 2007:867). This observation runs counter to the older assumption that language acquisition primarily works in a synthetic fashion, in which literally understood individual lexemes get combined into an understanding of more complex expressions. Instead, as empirical research on the acquisition of idiomatic expressions shows, children often rather learn set phrases in an unanalyzed form as "single chunks" (Häcki Buhofer 2007:861-862, 866). As Häcki-Buhofer (2007:861) observes, the learners' situation for children in their first language acquisition tends to be quite different from the one of second language learners: child first language learners have fewer problems with learning idioms because they approach them more holistically regarding their conventionalized composite meaning and are often unaware of the literal constituent meanings, which they only retrospectively learn. In this sense, these first language learners must "idiomatize" such phrases in retrospect. By contrast, as Wray (2007) also notes, compared to such child first language learners-that is, the "native speakers" of arguments on linguistic relativity-adult second language learners tend to rather follow a "too analytic approach":

The reason why child language acquisition (first and second) is so successful may be because of a resistance to unnecessary analysis [...]. Meanwhile, the perpetual struggle of so many adult language learners, particularly when taught outside the target language environment, may be a direct reflection of a too analytic approach [. . .] (Wray 2007:872)

Thus, second language learners often have difficulties in developing a holistic facility with native-like multiword strings, without immediately disassembling such expressions into their constituent parts:

This "analytical" approach will compete with any continuing ability to assign meaning and function to large units, and tend to push the learner into a preference for breaking down input into its constituent parts, rather than retaining it whole, even if it has a clear meaning and function at the holistic level. (Wray 2007:876)

In sum, child first language acquisition tends to be more holistic regarding composite phrases, requiring an ex-post "idiomatization" in realizing the discrepancy between the composite and the constituent meanings in expressions commonly regarded by native speakers as actually idiomatic. By contrast, adult learners tend to be more analytic in the course of second language acquisition, thus often creating two levels of meanings-the composite and an allegedly constituent one-and hence "idiomatize" complex expressions, even when these are probably not idiomatic at all from the point of view of native speakers. 
It is my contention that this is precisely what also happens in West Belfast for many adult second language learners of Irish in concrete situations of language acquisition and usage: because of a far more analytic approach to the Irish language than native speakers are likely to have, which creates word-for-word translations into English, the impression is created that complex expressions such as "Tá brón orm" = "I am sad" have a hidden second level of constituent meanings, which do not simply add up to the composite meaning of "I am sad" (see the examples given above). Instead, the "literal" level of "Sadness is on me" is seen as introducing a quite different conception of personhood and emotionality, compared to the one implied in the English "I am sad," even though both proclaim semantic equivalence on the composite level of conventional translations (in the conclusion I will come back to the question as to what constitutes a "literal" translation). Such an interpretation effectively "idiomatizes" composite Irish expressions, thus allowing for the widespread perception among Gaeilgeoirí of a peculiar worldview enshrined in the Irish language-a peculiar Irish worldview that is so very different from the one in English to justify the strong claims to linguistic relativity.

I would argue that this process is not only at work regarding the exemplary phrases on emotions and possessions, but also concerning the reinterpretation of place names as - compared to English-having an additional layer of meaning in the Irish language. There is, of course, no doubt that many Irish-language place names, etymologically speaking, do have a descriptive meaning in addition to the mere reference to the place they have named. Thus, the Irish-language place name for the town "Donegal" in the eponymous County Donegal is "Dún na nGall" (Bunachar Logainmneacha na hÉireann / Placenames Database of Ireland 2012), literally meaning "fort of the foreigners." However, the same is true for many place names in other languages, including English. Thus, etymologically speaking, "Newcastle" equally comprises the surplus meaning of referring not only to the English city of that name but also to a "new castle." The point I am trying to make is that although many proper names are etymologically significant and although native speakers obviously also can, and sometimes do, engage in debates about the descriptive surplus meanings of place names, their significance is often hardly noticed by native speakers in everyday life. However, adult second language learners, due to their strongly analytic approach to any new language, are much more likely to disassemble place names and hence idiomatize them through conceiving them as "speaking names" with an additional etymological meaning that is distinct from their semantics of pure reference as proper names. Hence native Irish speakers-whose allegedly distinct linguistic worldview we, after all, are trying to reconstruct within competing hypothetical arguments about linguistic relativity-are actually much less likely to think of a "fort of the foreigners" when talking of "Dún na nGall" than any person who acquires Irish as a second language. In the same vein, non-native English speakers are far more likely to think of a "new castle," when coming across the city of "Newcastle" than native English speakers generally would be (this hypothesis needs of course to be further tested). In other words: the idiomaticity of place names, distinguishing an etymological surplus meaning from the semantics of pure reference, is probably to a large extent a function of second language acquisition rather than of divergent worldviews actually enshrined in different languages.

To sum up: while we lack additional empirical data to sufficiently establish actual linguistic predispositions embedded in the Irish and English languages, I wish to put forward the hypothesis that what is perceived by local Gaeilgeoiri as a "discovery" of linguistic relativity in the course of learning Irish is most probably rather a strong effect of adult second language acquisition and misplaced idiomatization-that is, the interpretation of complex phrases in terms of idiomaticity that, from the point of view of native speakers, is most likely misplaced. In this process, analytic learners overdisassemble complex Irish expressions into their translated component meanings in ways that native learners simply do not, which causes the appearance of surplus meanings and idiomaticity, where-for native speakers at least-there, probably, are none. 
Because this misled idiomaticity of Irish expressions is directly caused by the specific context of an analytic process of language acquisition and as such underlies and systematically co-occurs with strong perceptions of a peculiar languagemediated worldview in Irish, this idiomatization becomes, in a sense, "indexical" of linguistic relativity, allowing to produce additional meanings from these juxtaposed events at the ideological level (see Hanks 2001 and Bucholtz and Hall 2004:378-379). This "indexical idiomatization" points toward the profound impact that Irish language acquisition and use by non-native speakers can have on reinforcing prevailing language ideologies, thus complementing iconical idiomatization in a highly powerful and productive ideological dialectic.

\section{Conclusion}

When I arrived for fieldwork in Belfast, I first had to get used to the fact that locals, in English, do not "speak," but "have" languages. Thus, "do you have Irish?" was a question that I often encountered in English-medium conversations. However, this turn of phrase, so strange to my German ears more attuned to what I learned in school as "Oxford English," is quite typical for the Hiberno-English variant spoken in Ireland, which-of course-is highly influenced by its Irish substratum. While, for me, linguistic differences thus already seemed to exist, compared to Oxford English, when locals spoke of "having Irish" in both Hiberno-English and Irish, for locals this level of "literal" translation was not sufficient-not "literal" enough-to "discover" any linguistic relativity. Instead, they had to further disassemble the Irish expression "Tá Gaeilge agam" / "I have Irish" into the even more detailed "literal" translation "Irish is at me" in order to sufficiently (indexically) idiomatize this phrase, thus "discovering" the fact that Irish speakers and English speakers truly saw the world differently. Given that the Irish construction "Tá . . . ag" can be used as the verb "to have" for both languages and other possessions, the "literal" translation "... is at" thus served, as described above, to substantiate the local thesis that the English language produced a more material outlook onto the world than did Irish.

It is ironic, however, that had I not become acquainted with the Hiberno-English expression of "having a language" (rather than "speaking" it) before I started learning Irish myself, my own "literal" translation of "Tá Gaeilge agam" - "I have Irish"could have led me to the exact opposite conclusion, namely, that Irish is the more "possessive" and "materialist" language, compared to both English and German, because in the latter one merely "speaks" a language, but does not "have" or "own" it as in Irish. Evidently, whether morphemes, words, phrases, clauses or sentences should be chosen as the reference point for "literal" translations is not in any sense self-evident, and the choices made subsequently have profoundly different consequences with regard to the alleged similarities and differences between languages, and hence the peculiarities that are projected as allegedly residing within a certain language.

This shows, again, that in the absence of additional empirical data, it might indeed be more plausible to assume that linguistic relativity in West Belfast is, first and foremost, an effect of quite different sociolinguistic factors. In this article, I have developed a hypothetical argument identifying two complementary and intertwining processes of "idiomatization," which have continuously (re-)created the local appearance of a profoundly singular worldview written into the Irish language. Starting from concrete language use in the highly specific context of adult second language acquisition, "indexical idiomatization" was proposed as emerging from a too analytic strategy (comparatively speaking) in acquiring a hitherto not practiced idiom. This, I argued, has led to the misplaced appearance of surplus meanings and idiomaticity of Irish expressions beyond the composite level of conventional translations into English, and hence to perceptions of linguistic relativity. However, as just shown with regard to my own experiences of learning Hiberno-English and Irish in Belfast as a native German speaker, the contents of such "observations" of linguistic 
relativity seem highly contingent upon one's own linguistic point of departure and scale of comparison. In other words: such alleged linguistic relativity seems truly rooted in the indexicality of a very peculiar from of idiomatization.

This indexical idiomatization, causing misleading perceptions of linguistic relativity, is likely to be a general phenomenon among adult second language learners. This raises thorny issues with regard to semantic explorations of key concepts in foreign languages, which are so common in anthropological research: to what an extent do these actually reflect relevant meanings of the target language and "culture" itself or rather of the observer's interlanguage, which is likely to be too analytic, hence often inappropriately idiomatic and, as such, in semantic excess?

I further argued that this indexical idiomatization, causing the impression of linguistic relativity on the basis of actual language practice, intersects with and reinforces a complementary process of "iconical idiomatization," which independently prefigures and predicts linguistic relativity at the level of language ideologies. Within the wider context of Northern Ireland, and directly related to the long-term ethno-nationalist conflict about its constitutional status, a dominant strand within local language ideologies has for a long time conceived the Irish language in terms of the iconical idiom of the Irish nation. Many Irish Catholics, learning Irish during years of violent conflict, have thus done so in terms that projected the language to be both a crucial ethnic marker of Irishness and as embodying a distinctive Irish worldview. Iconical idiomatization as the process of making a "foreign" (i.e., hitherto not practiced) language one's own conceptually as well as practically through actual language acquisition thus already predisposed many Northern Irish Gaeilgeoirí right from the beginning to think of Irish in neo-Whorfian terms.

What Bucholtz and Hall observe with regard to processes of identity formation thus arguably holds true also concerning the production of "linguistic relativity": "Iconization and indexicality are converse processes [. . .]: indexicality produces ideology through practice, while iconization represents practice through ideology" (Bucholtz and Hall 2004:380). It is in this sense that iconical and indexical idiomatizations have tended to mutually reinforce each other in a dialectical movement, sustaining strong notions of linguistic relativity with regard to a language treated as iconic of one of the parties in ethno-nationalist conflict. It is under such conditions of a close interconnection between language and ethnicity in the context of violent conflict that, I believe, neo-Whorfian arguments can gain strong credence, even if future research based on additional data might show that the alternative hypothesis put forward in this text might actually better account for such strong beliefs in linguistic relativity.

\section{Notes}

Acknowledgments. I am grateful to the Max Planck Institute for Social Anthropology in Halle, Germany for financially supporting as well as intellectually inspiring my research, on which this text is based. Earlier versions were presented at the Workshop on the occasion of the 60th birthday of Günther Schlee at the Max Planck Institute for Social Anthropology as well as at the Emergent Ethnographies Seminar at the Department of Social Anthropology (University of Cape Town). I am grateful to Helen Macdonald, Gordon McCoy, Francis Nyamnjoh, Günther Schlee, Andrew Spiegel, Ilana van Wyk, Iwar Werlen, Julia Zenker, and the Journal of Linguistic Anthropology editors and anonymous reviewers for critical engagements and spirited discussions. All errors that remain are my own.

1. Ulster-Scots has been portrayed as the endangered heritage language of the Protestant Unionist Loyalist community in Northern Ireland, even though some, especially from the Irish Catholic Nationalist community, contest its status as "language" and dismiss it as a mere "dialect" of English; for further discussions of Ulster-Scots with regard to Irish, see McCoy and O'Reilly (2002) and Pritchard (2004).

2. O'Rourke and Ramallo (2013) investigate the tensions and paradoxes that may emerge between "native" first language speakers and "new speakers" within the "native" language revival of Galician. For a study mapping the contested constructions of the notion of 
"heritage language learners" in the context of Japanese language schools in the United States, see Doerr and Lee (2013).

3. For a more extensive discussion of my research methodology, see Zenker (2013:36-40).

4. For a more comprehensive discussion of overlapping and cross-cutting language ideologies within different dimensions and at variable scales, see Zenker (2013:121-145).

5. See especially Hindley (1990), Andrews (1997, 2000a, 2000b), Mac Póilin (1997, 2003a, 2003b, 2006), Mac Corraidh (2006), and De Brún (2006a).

6. See especially Maguire (1991), Nig Uidhir (2006), McCoy (1997a, 1997b, 2006), Kachuk (1993, 1994), and O'Reilly (1996, 1997, 1999).

7. According to Patrick McKay (2006:16), the correct translation for Béal Feirste is "mouth of (or approach to) the sand-bank ford," even though it is a common misconception that it means "mouth of the river Farset."

8. For a discussion of similar discourses defending languages against various kinds of dangers, see Heller and Duchêne (2007).

\section{References}

Andrews, Liam S.

1997 The Very Dogs in Belfast Will Bark in Irish: The Unionist Government and the Irish Language 1921-43. In The Irish Language in Northern Ireland. A. Mac Póilin, ed. Pp. 49-94. Belfast: Ultach Trust.

2000a Northern Nationalists and the Politics of the Irish Language: The Historical Background. In Language and Politics: Northern Ireland, the Republic of Ireland and Scotland. J. M. Kirk and D. P. Ó Baoill, eds. Pp. 45-64. Belfast: Cló Ollscoil na Banríona.

2000b Unionism and Nationalism and the Irish Language, 1893-1933. Ph.D. thesis, Queen's University Belfast.

Antonini, Rachele, Karen Corrigan, and Wei Li

2002 The Irish Language in the Republic of Ireland and in Northern Ireland. Sociolinguistica 16:118-128.

Berlin, Brent, and Paul Kay

1969 Basic Color Terms: Their Universality and Evolution. Berkeley: University of California Press.

Bloom, Alfred $\mathrm{H}$.

1981 The Linguistic Shaping of Thought: A Study in the Impact of Language on Thinking in China and the West. Hillsdale, NJ: Lawrence Erlbaum.

Brown, Roger W., and Eric H. Lenneberg

1954 A Study in Language and Cognition. Journal of Abnormal and Social Psychology 49:454-462.

1958 Studies in Linguistic Relativity. In Readings in Social Psychology. E. E. Maccoby, T. M. Newcomb and E. L. Hartley, eds. Pp. 9-18. New York: Henry Holt.

Bucholtz, Mary, and Kira Hall

2004 Language and Identity. In A Companion to Linguistic Anthropology. A. Duranti, ed. Pp. 369-394. Malden: Blackwell.

Bunachar Logainmneacha na hÉireann / Placenames Database of Ireland

2012 Dún na nGall/Donegal (town), Donegal.

Coakley, John

2007 National Identity in Northern Ireland: Stability or Change? Nations and Nationalism 13(4):573-597.

Coulter, Colin

1999 Contemporary Northern Irish Society: An Introduction. London and Sterling: Pluto Press.

Crowley, Tony

2005 Wars of Words: The Politics of Language in Ireland 1537-2004. Oxford: Oxford University Press.

2006 The Political Production of a Language: The Case of Ulster-Scots. Journal of Linguistic Anthropology 16(1):23-35.

Cumming, Sam

2012 Names. In The Stanford Encyclopedia of Philosophy. Spring edition. Edward N. Zalta, ed. Stanford: Stanford University Press. 
Davidson, Donald

1989 The Myth of the Subjective. In Relativism. M. Krausz, ed. Pp. 159-172. Notre Dame:

University of Notre Dame Press.

De Brún, Fionntán, ed.

2006a Belfast and the Irish Language. Dublin: Four Courts.

2006b Introduction. In Belfast and the Irish Language. F. De Brún, ed. Pp. 7-14. Dublin: Four Courts.

Doerr, Neriko Musha, ed.

2009 The Native Speaker Concept: Ethnographic Investigations of Native Speaker Effects. Berlin: Mouton de Gruyter.

Doerr, Neriko Musha, and Kiri Lee

2013 Constructing the Heritage Language Learner: Knowledge, Power, and New Subjectivities. Berlin: Mouton de Gruyter.

Doherty, Paul, and Michael Poole

2000 Living Apart in Belfast: Residential Segregation in a Context of Ethnic Conflict. In Ethnicity and Housing: Accommodating Differences. F. W. Boal, ed. Pp. 179-189. Aldershot: Ashgate.

Errington, Joseph

2001 Ideology. In Key Terms in Language and Culture. A. Duranti, ed. Pp. 110-112. Malden: Blackwell.

Feldman, Allen

1991 Formations of Violence: The Narrative of the Body and Political Terror in Northern Ireland. Chicago: University of Chicago Press.

Gal, Susan, and Judith T. Irvine

1995 The Boundaries of Languages and Disciplines: How Ideologies Construct Difference.

Social Research 62(4):967-1001.

Garland, Jennifer

2010 "I Am Under Cool": Humorous Mock-Translation as a Claim to Expertise in an Irish Language Class. Sociolinguistic Studies 4(1):27-44.

Häcki Buhofer, Annelies

2007 Phraseme im Erstspracherwerb. In Phraseologie/Phraseology-Ein internationales Handbuch zeitgenössischer Forschung. H. Burger, D. Dobrovol'ski, P. Kühn and N. Norrick, eds. Pp. 854-869. Berlin: de Gruyter.

Hanks, William F.

2001 Indexicality. In Key Terms in Language and Culture. A. Duranti, ed. Pp. 119-121. Malden: Blackwell.

Heller, Monica and Alexandre Duchêne, eds.

2007 Discourses of Endangerment: Ideology and Interest in the Defence of Languages. London: Continuum.

Herder, Johann Gottfried

2002[1765-1793] Philosophical writings. Michael N. Forster, ed. Cambridge: Cambridge University Press.

Hindley, Reg

1990 The Death of the Irish Language: A Qualified Obituary. London and New York: Routledge.

Humboldt, Wilhelm von

1988[1836] On Language: The Diversity of Human Language-Structure and Its Influence on the Mental Development of Mankind. Cambridge: Cambridge University Press.

Hutchinson, John

1987 The Dynamics of Cultural Nationalism: The Gaelic Revival and the Creation of the Irish Nation State. London and Boston: Allen \& Unwin.

Irvine, Judith T., and Susan Gal

2009 Language Ideology and Linguistic Differentiation. In Linguistic Anthropology: A Reader. 2nd edition. A. Duranti, ed. Pp. 402-434. Malden: Wiley-Blackwell.

Jaffe, Alexandra M.

1999 Ideologies in Action: Language Politics on Corsica. Berlin: Mouton de Gruyter.

Kachuk, Patricia Mary Catherine

1993 Irish Language Activism in West Belfast: A Resistance to British Cultural Hegemony. Ph.D. thesis, Department of Anthropology, University of British Columbia.

1994 A Resistance to British Cultural Hegemony: Irish Language Activism in West Belfast. Anthropologica 36:135-154. 
Kanavou, Nikoletta

2011 Aristophanes' Comedy of Names: A Study of Speaking Names in Aristophanes. Berlin and New York: De Gruyter.

Kroskrity, Paul V., ed.

2000 Regimes of Language: Ideologies, Polities, and Identities. Santa Fe, NM: School of American Research Press.

2004 Language Ideologies. In A Companion to Linguistic Anthropology. A. Duranti, ed. Pp. 496-517. Malden: Blackwell.

Lucy, John A.

1992 Grammatical Categories and Cognition: A Case Study of the Linguistic Relativity Hypothesis. Cambridge: Cambridge University Press.

1997 Linguistic Relativity. Annual Review of Anthropology 26:291-312.

Lucy, John A., and Richard A. Shweder

1979 Whorf and His Critics: Linguistic and Nonlinguistic Influences on Color Memory. American Anthropologist 81:581-615.

Mac Corraidh, Seán

2006 Irish-Medium Education in Belfast. In Belfast and the Irish Language. F. De Brún, ed. Pp. 177-183. Dublin: Four Courts.

Mac Giolla Chríost, Diarmait

2012 Jailtacht: The Irish Language, Symbolic Power and Political Violence in Northern Ireland, 1972-2008. Cardiff: University of Wales Press.

Mac Giolla Easpaig, Dónall

2008 Placenames Policy and Its Implementation. In A New View of the Irish Language. C. Nic Pháidín and S. Ó Cearnaigh, eds. Pp. 164-177. Dublin: Cois Life.

Mac Póilin, Aodán, ed.

1997 The Irish Language in Northern Ireland. Belfast: Ultach Trust.

2003a The Irish Language in Belfast After 1900. In The Cities of Belfast. N. Allen and A. Kelly, eds. Pp. 127-151. Dublin and Portland: Four Courts Press.

2003b The Irish Language in Belfast Until 1900. In The Cities of Belfast. N. Allen and A. Kelly, eds. Pp. 41-61. Dublin and Portland: Four Courts Press.

2006 Irish in Belfast, 1892-1960: From the Gaelic League to Cumann Chluain Ard. In Belfast and the Irish Language. F. De Brún, ed. Pp. 114-135. Dublin: Four Courts.

Macdonald, Sharon

1997 Reimagining Culture: Histories, Identities, and the Gaelic Renaissance. Oxford and New York: Berg.

Maguire, Gabrielle

1991 Our Own Language: An Irish Initiative. Clevedon: Multilingual Matters.

McArthur, Tom

1992 The Oxford Companion to the English Language. Oxford and New York: Oxford University Press.

McCoy, Gordon

1997a Protestant Learners of Irish in Northern Ireland. In The Irish Language in Northern Ireland. A. Mac Póilin, ed. Pp. 131-169. Belfast: Ultach Trust.

1997b Protestants and the Irish Language in Northern Ireland. Ph.D. thesis, Faculty of Arts, Queen's University Belfast.

2006 Protestants and the Irish Language in Belfast. In Belfast and the Irish Language. F. De Brún, ed. Pp. 147-176. Dublin: Four Courts.

McCoy, Gordon, and Camille O'Reilly

2002 The Essential Ulster: Division, Diversity, and the Ulster-Scots Language Movement. Irish Journal of Anthropology 6:57-90.

McDonald, Maryon

1989 “We Are Not French!": Language, Culture, and Identity in Brittany. London and New York: Routledge.

McKay, Patrick

2006 Belfast Place-Names and the Irish Language. In Belfast and the Irish Language. F. De Brún, ed. Pp. 15-35. Dublin: Four Courts.

McKeown, Laurence

2001 Out of Time: Irish Republican Prisoners, Long Kesh, 1972-2000. Belfast: Beyond the Pale. 
Merriam-Webster

1972 Webster's Seventh New Collegiate Dictionary: Based on "Webster's Third New International Dictionary." Springfield, MA: Merriam.

Mill, John Stuart

1973[1843] A System of Logic, Ratiocinative and Inductive: Being a Connected View of the Principles of Evidence and the Methods of Scientific Investigation. Toronto and London: University of Toronto Press and Routledge and Kegan Paul.

Nic Craith, Máiréad

1999 Irish Speakers in Northern Ireland, and the Good Friday Agreement. Journal of Multilingual and Multicultural Development 20(6):494-507.

Nig Uidhir, Gabrielle

2006 The Shaw's Road Urban Gaeltacht: Role and Impact. In Belfast and the Irish Language. F. De Brún, ed. Pp. 136-146. Dublin: Four Courts.

O’Reilly, Camille

1996 The Irish Language_-Litmus Test for Equality? Competing Discourses of Identity, Parity of Esteem, and the Peace Process. Irish Journal of Sociology 6:154-178.

1997 Nationalists and the Irish Language in Northern Ireland: Competing Perspectives. In The Irish Language in Northern Ireland. A. Mac Póilin, ed. Pp. 95-130. Belfast: Ultach Trust.

1999 The Irish Language in Northern Ireland: The Politics of Culture and Identity. Basingstoke, Hampshire, and New York: Macmillan/St. Martin's.

O'Rourke, Bernadette, and Fernando Ramallo

2013 Competing Ideologies of Linguistic Authority Amongst New Speakers in Contemporary Galicia. Language in Society 42(3):287-305.

Ó Murchú, Máirtín

2000 Irish. In Encyclopedia of the Languages of Europe. G. Price, ed. Pp. 243-250. Oxford: Blackwell.

Piaget, Jean

1928 Judgment and Reasoning in the Child. London and New York: K. Paul Trench/ Harcourt, Brace.

Price, Glanville

2000 Celtic Languages. In Encyclopedia of the Languages of Europe. G. Price, ed. Pp. 83-84. Oxford: Blackwell.

Pritchard, Rosalind M. O.

2004 Protestants and the Irish Language: Historical Heritage and Current Attitudes in Northern Ireland. Journal of Multilingual and Multicultural Development 25(1):62.

Purdon, Edward

1999 The Story of the Irish Language. Dublin: Mercier Press.

Rosch, Eleanor H.

1977 Linguistic Relativity. In Thinking: Readings in Cognitive Science. P. N. Johnson-Laird and P. C. Wason, eds. Pp. 501-522. Cambridge: Cambridge University Press.

Schieffelin, Bambi B., Kathryn A. Woolard and Paul V. Kroskrity, eds.

1998 Language Ideologies: Practice and Theory. New York: Oxford University Press.

Schlee, Günther

2008 How Enemies Are Made: Towards a Theory of Ethnic and Religious Conflicts. Oxford and New York: Berghahn Books.

Schlesinger, I. M.

1991 The Wax and Wane of Whorfian Views. In The Influence of Language on Culture and Thought/Essays in Honor of Joshua A. Fishman's Sixty-Fifth Birthday. R. L. Cooper and B. Spolsky, eds. Pp. 7-44. Berlin and New York: Mouton de Gruyter.

Schrijver, Peter

2000 Indo-European Languages. In Encyclopedia of the Languages of Europe. G. Price, ed. Pp. 239-242. Oxford: Blackwell.

Schweizer, Thomas

1998 Epistemology: The Nature and Validation of Anthropological Knowledge. In Handbook of Methods in Cultural Anthropology. H. R. Bernard, ed. Pp. 39-87. Walnut Creek, CA: AltaMira.

Silverstein, Michael

1979 Language Structure and Linguistic Ideology. In The Elements: A Parasession on Linguistic Units and Levels. P. R. Clyne, W. F. Hanks and C. L. Hofbauer, eds. Pp. 193-247. Chicago: Chicago Linguistic Society. 
1985 Language and the Culture of Gender: At the Intersection of Structure, Usage and Ideology. In Semiotic Mediation: Sociocultural and Psychological Perspectives. E. Mertz and R. J. Parmentier, eds. Pp. 219-259. Orlando: Academic Press.

Szabó, Zoltán Gendler

2008 Compositionality. In The Stanford Encyclopedia of Philosophy (Winter edition). E. N. Zalta, ed. http://plato.stanford.edu/archives/win2008/entries/compositionality/, accessed June 28, 2011.

Trew, Karen

1998 The Northern Irish Identity. In A Question of Identity. A. J. Kershen, ed. Pp. 60-76. Aldershot: Ashgate.

Urla, Jacqueline

1988 Ethnic Protest and Social Planning: A Look at Basque Language Revival. Cultural Anthropology 3(4):379-394.

Werlen, Iwar

2002 Sprachliche Relativität: eine problemorientierte Einführung. Tübingen: Francke.

Whorf, Benjamin Lee

1956 Language, Thought, and Reality: Selected Writings. Cambridge: Technology Press of Massachusetts Institute of Technology.

Woolard, Kathryn A.

1998 Introduction: Language Ideology as a Field of Inquiry. In Language Ideologies: Practice and Theory. B. B. Schieffelin, K. A. Woolard and P. V. Kroskrity, eds. Pp. 3-47. New York: Oxford University Press.

Woolard, Kathryn A., and Bambi B. Schieffelin

1994 Language Ideology. Annual Review of Anthropology 23:55-82.

Wray, Alison

2007 Set Phrases in Second Language Acquisition. In Phraseologie/Phraseology-Ein internationales Handbuch zeitgenössischer Forschung. H. Burger, D. Dobrovol'ski, P. Kühn and N. Norrick, eds. Pp. 870-881. Berlin: de Gruyter.

Zenker, Olaf

2006 De Facto Exclusion Through Discursive Inclusion: Autochthony in Discourses on Irishness and Politics in Catholic West Belfast. Paideuma 52:183-195.

2009 Autochthony and Activism Among Contemporary Irish Nationalists in Northern Ireland, or: If "Civic" Nationalists are "Ethno"-Cultural Revivalists, What Remains of the Civic/Ethnic Divide? [and postscript by Joep Leerssen and reply]. Nations and Nationalism 15(4):696-722.

2010a Between the Lines: Republicanism, Dissenters and the Politics of Meta-Trauma in the Northern Irish Conflict. Social Science \& Medicine 71(2):236-243.

2010b Language Matters: Reflexive Notes on Representing the Irish Language Revival in Catholic West Belfast. In Beyond Writing Culture: Current Intersections of Epistemologies and Representational Practices. O. Zenker and K. Kumoll, eds. Pp. 121-138. New York and Oxford: Berghahn.

2011 Autochthony, Ethnicity, Indigeneity and Nationalism: Time-Honouring and StateOriented Modes of Rooting Individual-Territory-Group-Triads in a Globalising World. Critique of Anthropology 31(1):63-81.

2012 On Prophets, Godfathers, Rebels, and Prostitutes: Distributed Agency in the Irish Language Revival of Northern Ireland. Zeitschrift für Ethnologie 137(1):23-45.

2013 Irish/ness Is all Around Us: Language Revivalism and the Culture of Ethnic Identity in Northern Ireland. New York and Oxford: Berghahn. 